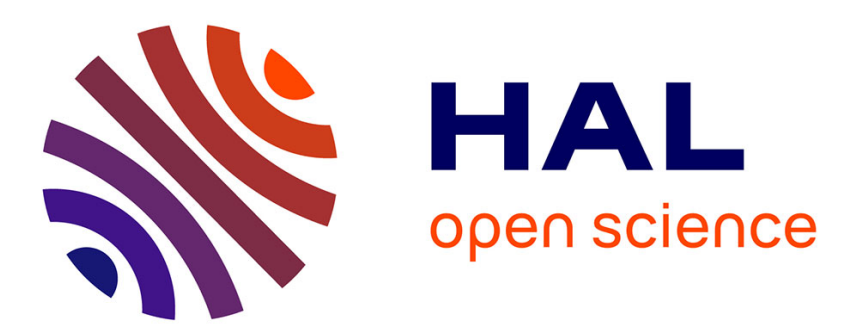

\title{
Preserved lignin structures in Miocene-aged lignite lithotypes, Bulgaria.
}

\author{
Maya Stefanova, O. Maman, Bernard Guillet, Jean-Robert Disnar
}

\section{To cite this version:}

Maya Stefanova, O. Maman, Bernard Guillet, Jean-Robert Disnar. Preserved lignin structures in Miocene-aged lignite lithotypes, Bulgaria.. Fuel, 2004, 83, pp.123-128. 10.1016/S0016-2361(03)000371. hal-00069184

\section{HAL Id: hal-00069184 \\ https://hal-insu.archives-ouvertes.fr/hal-00069184}

Submitted on 16 May 2006

HAL is a multi-disciplinary open access archive for the deposit and dissemination of scientific research documents, whether they are published or not. The documents may come from teaching and research institutions in France or abroad, or from public or private research centers.
L'archive ouverte pluridisciplinaire HAL, est destinée au dépôt et à la diffusion de documents scientifiques de niveau recherche, publiés ou non, émanant des établissements d'enseignement et de recherche français ou étrangers, des laboratoires publics ou privés. 


\title{
Preserved lignin structures in Miocene-aged lignite lithotypes, Bulgaria
}

\author{
M. Stefanova, O. Maman, B. Guillet and J. -R. Disnar \\ ISTO, UMR 6113, Lab. Org. Geochem., University of Orleans, BP 6759, 45067, Orleans \\ Cedex 2, France
}

\begin{abstract}
Contents of preserved lignin structures in Miocene-aged lignite lithotypes were determined. Phenol aldehydes, ketones and acids released from lignin by $\mathrm{CuO}$ oxidative hydrolysis were separated by capillary zone electrophoresis (CZE). Products of degradation were separated and identified by GC-MS to confirm CZE data and to complement composition data. The following values for the contents of preserved lignin structures in lignite lithotypes were determined (in wt\%): xylain, 8.5; humovitrain, 6.7; liptain, 6.4; and humoclarain, 3.3. Some fatty acids, negligible contents of benzene polycarboxylic acids and their hydroxy/methoxy counterparts were also observed using GC-MS.
\end{abstract}

Author Keywords: Coal; Lignin; Capillary electrophoresis

\section{Introduction}

The general consensus today is that the coalification process involves a selective preservation of certain resistant plant remains followed by some reorganisation of the biopolymers that survive [1]. During peatification and coalification the methoxyl groups from guaiacyl/syringyl structures are lost first via demethylation and resulting alkylated catechols are converted to alkylated phenols $[\underline{2}, \underline{3}, \underline{4}, \underline{5}$ and $\underline{6}]$. At the biochemical stage hemicellulose is completely lost, cellulose content reduced, and lignin-derived structures selectively preserved. It is well documented that integral parts of lignin are incorporated into fossil organic matter, i.e. in kerogens, coals, sediments, soils, humic substances, etc. Thus the preserved lignin-derived structures provide an ideal tracer for the original inputs of vascular plant material.

Hayatsu et al. [7] studied the alkaline $\mathrm{CuO}$ oxidation of coals at $170-200{ }^{\circ} \mathrm{C}$ in order to estimate preserved lignin structures. They demonstrated that lignin-like polymers were incorporated into macromolecules but were still identifiable in lower rank coals. The authors concluded that: (i) the treatment resulted in hydrolytic oxidation of ether linkages in the aliphatic side chains of aromatics; (ii) did not split $\mathrm{C}-\mathrm{C}$ bonds; (iii) effectively have oxidised aliphatic chains with heteroatoms; (iv) and, aromatic rings were not destroyed.

The oxidation technique allowed evaluation of the amount, quality, and stage of degradation of lignin in fossil samples. The drawbacks of the method are as follows [4] : (i) the technique is time-consuming; (ii) the microbial altered lignin monomers (catechols) are not analysed inasmuch are oxidised to low molecular fatty acids.

Hedges and Mann []ㅡ divided the various aldehydic, ketonic, and acidic phenolic compounds produced during alkaline $\mathrm{CuO}$ oxidation of geological samples in three groups based on the other substituents of the aromatic nuclei interpreted to be inherited from lignin. In this way 
the general vascular plant sources in paleoenvironment can be identified. The concentrations of vanillyl (V), syringyl (S) and cinnamyl (C) phenolic units were related to plant variety, lignin concentration, tissue type, and degree of fungal alternation during deposition. The data allowed compositional regions to be distinguished for: non-vascular plants; gymnosperm woods (non-flowering plants including conifers); non-woody gymnosperm tissues; angiosperms (flowering plants including hard-wood trees); non-woody angiosperms (herbs, grasses, etc.); The ratios of the concentrations for different types of phenols can be plotted in a two-dimensional diagram and regions for source assignments were defined []. The approach is improved and applied at different areas of organic geochemistry [ $\underline{1}, \underline{9}$ and $\underline{10}]$.

Our ongoing research is devoted to Miocene-aged lignite lithotypes. The contents of ligninderived phenols in products of alkaline $\mathrm{CuO}$ oxidation were determined by coupling with capillary zone electrophoresis (CZE). The data were quantitatively interpreted and compared with mass spectral study.

\section{Experimental}

Hand-picked lithotypes from Miocene lignite 'Maritza-Iztok', Bulgaria (Ro, 0.18\%) were under study. The following macroscopically distinguished lithotypes were used: xylain $(\mathrm{X})$, humovitrain (HV), liptain (L) and humoclarain (HK). In $\underline{\text { Table } 1}$ are gathered some characteristics of the samples.

\begin{tabular}{|c|c|c|c|c|}
\hline \multirow[t]{2}{*}{ Characteristics } & \multicolumn{4}{|c|}{ Lithotype } \\
\hline & Xylain & Humo-vitrain & Liptain & Humo-clarain \\
\hline \multicolumn{5}{|l|}{ Proximate analysis } \\
\hline Moisture, $(\%)$ & 9.8 & 13.9 & 12.7 & 22.9 \\
\hline Ash $(d B)$ & 0.8 & 3.4 & 0.4 & 22.8 \\
\hline Volatile matter, (daf) & 58.8 & 52.8 & 68.1 & 60.5 \\
\hline \multicolumn{5}{|l|}{ Ultimate analysis, (daf) } \\
\hline $\mathrm{C}$ & 67.3 & 65.8 & 72.1 & 65.1 \\
\hline $\mathrm{H}$ & 6.1 & 5.5 & 7.2 & 6.6 \\
\hline \multicolumn{5}{|l|}{ Rock-Eval pyrolysis data } \\
\hline TOC (wt $\%)$ & 62.3 & 61.1 & 60.7 & 63.9 \\
\hline $\mathrm{S}_{2}$ (mg HC/g sample) & 137.7 & 89.4 & 153.1 & 140.9 \\
\hline $\mathrm{HI}(\mathrm{mg} \mathrm{HC} / \mathrm{g} \mathrm{TOC})$ & 221 & 146 & 252 & 220 \\
\hline$T_{\max }\left({ }^{\circ} \mathrm{C}\right)$ & 375 & 374 & 368 & 394 \\
\hline
\end{tabular}

Table 1. Characteristics of lignte lithotypes (wt $\%)$

Rock-Eval ${ }^{\mathrm{TM}}$ pyrolysis was carried out using an Oil Show Analyser (OSA; Delsi Instrument), under standard conditions, in cycle 3 (i.e. with programmed pyrolysis from 200 to $600{ }^{\circ} \mathrm{C}$ at a rate of $\left.30^{\circ} \mathrm{C} / \mathrm{min}\right)$.

Alkaline $\mathrm{CuO}$ oxidation was carried out in Teflon-lined steel bombs placed at $170{ }^{\circ} \mathrm{C}$ for $4 \mathrm{~h}$ [11]. After cooling, 2,4,5-trimethoxybenzoic acid was introduced as an internal standard. 
Then lignin phenols were extracted with peroxide free diethyl ether. After solvent evaporation, lignin phenols were dissolved in methanol and kept under nitrogen in sealed vessels.

Lignin monomers separation was performed by CZE according to Maman et al. [10 and 12]. Eleven phenol compounds were separated by CZE with P/ACE 5510 system Beckman instrument equipped with a fused silica capillary $(57 \mathrm{~cm} \times 50 \mu \mathrm{m})$. An UV detector was set at absorbency $214 \mathrm{~nm}$ through the capillary at $50 \mathrm{~cm}$ from the injection point. The system was supported by PC GOLD-3M40 software Beckman. After the CZE study the products of $\mathrm{CuO}$ oxidation were methylated by $\mathrm{CH}_{2} \mathrm{~N}_{2}$ and subjected to $\mathrm{GC}$ and $\mathrm{GC}-\mathrm{MS}$ study.

The methylated fractions were analysed on a Perkin-Elmer Autosystem XL gas chromatograph equipped with $\mathrm{CP}$ sil $5 \mathrm{CB}$ column $(0.22 \mathrm{~mm} \times 30 \mathrm{~m} ; 0.25 \mu \mathrm{m}$ film thickness $)$, a flame ionisation detector $\left(300{ }^{\circ} \mathrm{C}\right.$, and a split/splitless capillary injector maintained at 300 ${ }^{\circ} \mathrm{C}$ used in the splitless mode (valve reopened one min after injection). After 1 min hold at 50 ${ }^{\circ} \mathrm{C}$ the oven temperature was increase from 50 to $120{ }^{\circ} \mathrm{C}$ at $30^{\circ} \mathrm{C} / \mathrm{min}$, and then from 120 to $300{ }^{\circ} \mathrm{C}$ at $5^{\circ} / \mathrm{min}$, maintaining this final temperature for a period of $1 \mathrm{~h}$.

GC-MS study is performed with a Varian 300 chromatograph connected to an ITD 800 (Finnigan Mat) by $2 \mathrm{~m}$ capillary interface heated to $300{ }^{\circ} \mathrm{C}$. Other $\mathrm{GC}$ conditions were identical to those described earlier. Operating conditions for the ion trap were temperature $220{ }^{\circ} \mathrm{C}$; ionisation energy $80 \mathrm{eV}$; Tscan $2 \mathrm{~s}$ from 50 to $500 \mathrm{amu}$. Peak identification was verified by coinjection of standard phenols, in CZE, and by comparison with NIST library data, in GC-MS.

\section{Results and discussion}

Lignin polymers cannot be analysed without prior chemical degradation treatment to release smaller molecules amenable to chromatographic study. Hedges and Mann []ㅡ proposed compositional data for lignin-related phenols produced during $\mathrm{CuO}$ oxidation of vascular and non-vascular plant tissues to be considered as source parameters. The authors have grouped the phenols as follows:

Vanillyl phenols (V):

3-methoxy-4-hydroxybenzaldehyde (Vanillin)

3-methoxy-4-hydroxyacetophenone (Acetovanillone)

3-methoxy-4-hydroxybenzoic acid (Vanillic acid);

Syringyl phenols (S):

3,5-dimethoxy-4-hydroxybenzaldehyde (Syringe aldehyde)

3,5-dimethoxy-4-hydroxyacetophenone (Acetosyringone)

3,5-dimethoxy-4-hydroxybenzoic acid (Syringic acid);

Cinnamic acids (C):

3-(3-methoxy-4-hydroxyphenyl)-propenoic acid (Ferulic acid)

3-(4-hydroxyphenyl)-propenoic acid ( $p$-Coumaric acid); 
p-Hydroxybenzoic phenols $\mathbf{( H ) :}$

4-Hydroxybenzaldehyde

4-Hydroxyacetophenone

4-Hydroxybenzoic acid;

Total lignin content, in wt $\%$, or expressed as $w t \%$ in organic carbon $(\Lambda)$, is determined as the sum of the contents of four phenolic type units. Vanillyl and syringyl compounds are derived from the oxidation of the coniferyl and sinapyl moieties of lignin, respectively. Ferulic and $p-$ coumaric acids are believed to be linked to lignin polymers by ester bonds that are hydrolysed readily but not oxidised. 4-Hydroxybenzoic compounds could be partly derived from other sources than lignin and are seldom employed for correlation purposes. Typical electrophoregrams for standard mixture of the 11 phenolic compound (A) and of xylain products obtained after $\mathrm{CuO}$ oxidation (B) are shown in Fig. 1.

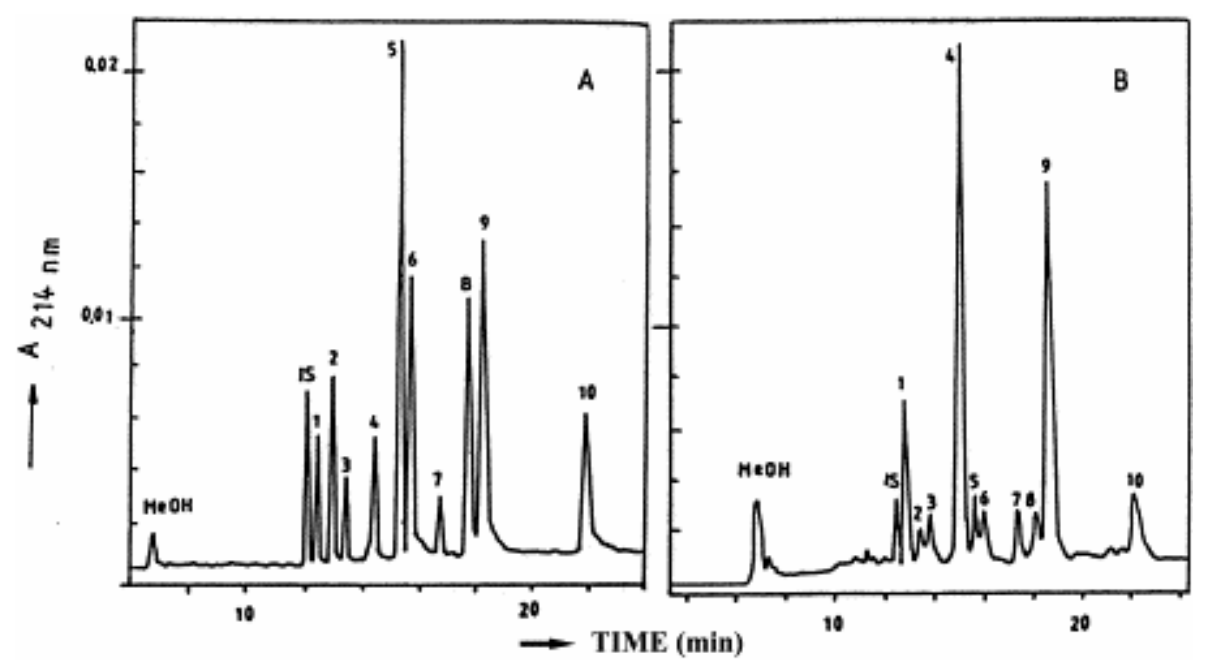

Fig. 1. Capillary zone electrophoregrams; (A) standard mixture; (B) products of CuO oxidation of xylain; Peak assignment: IS, internal standard (2,4,5-trimethoxybenzoic acid); (1) 3-methoxy-4-hydroxyacetophenone (acetovanillone); (2) 3,5-dimethoxy-4-hydroxybenzaldehyde (syringe aldehyde); (3) 4-hydroxyacetophenone; (4) 3-methoxy-4-hydroxybenzaldehyde (vanillin); (5) 3,5-dimethoxy-4-hydroxybenzoic acid (syringic acid); (6) 3(3-methoxy-4-hydroxyphenyl)-propenoic acid (ferulic acid); (7) 4-hydroxybenzaldehyde; (8) 3-(4hydroxyphenyl)-propenoic acid (coumaric acid); (9) 3-methoxy-4-hydroxybenzoic acid (vanillic acid); (10) 4hydroxybenzoic acid.

The lignin of the two most abundant classes of vascular plant, the Gymnospermae and the Angiospermae, could be distinguished according to specific position in S/V vs. C/V diagram, where $\mathrm{S}, \mathrm{C}, \mathrm{V}$ are the ratios of the syringyl, cinnamyl and vanillyl contents. In this diagram gymnosperm wood, non-woody gymnosperm tissue, angiosperm wood, and non-woody angiosperm tissues are resolved into non-overlapping areas []].

The data for lignite lithotypes subjected to alkaline $\mathrm{CuO}$ oxidation are present in Table 2 . The values for the lignin phenol yields are expressed as $\mathrm{wt} \%$ coal (daf basis). The maximum value calculated in $\mathrm{wt} \%$ organic carbon, was determined for xylain, $\Lambda=12.7$ and decreased with humification as suggested by the value $\Lambda=5.2 \mathrm{wt} . \%$ organic carbon determined for humoclarain. 


\begin{tabular}{lcccc}
\hline Phenolic units & Lithotype & & \\
\cline { 2 - 5 } & Xylain & $\begin{array}{c}\text { Humo- } \\
\text { vitrain }\end{array}$ & Liptain & $\begin{array}{c}\text { Humo- } \\
\text { clarain }\end{array}$ \\
& & & & \\
Yield of phenols & & & & 3.3 \\
in wt\% & 8.5 & 6.7 & 6.4 & 5.2 \\
A in wt\% organic carbon & 12.7 & 10.2 & 8.9 & 0.87 \\
Ratio acid/aldehyde (Ad/Al) & 0.67 & 0.64 & 0.67 & \\
Distribution of phenolic units, & & & & 73.6 \\
(in \% of total phenols) & & & & 2.3 \\
Vanillyl units (V) & 78.8 & 95.0 & 72.9 & 0.0 \\
Syringyl units (S) & 2.8 & 0.0 & 0.0 & 24.0 \\
Cinnamyl units (C) & 5.3 & 0.0 & 1.0 & \\
p-Hydroxyphenyl units (H) & 13.1 & 4.9 & 26.1 & \\
\hline
\end{tabular}

Table 2. Yields of lignin-derived phenol and their distribution in structural types

Acid/aldehyde ratios ( $\mathrm{Ad} / \mathrm{Al})$, determined on the base contents of vanillic acid/vanillin, similar for xylain, humovitrain and liptain, are approximately 0.65 . The ratio magnitude sharply increased to 0.87 for humoclarain. This latter value provides an indication for fungal degradation at $\mathrm{C} \alpha$ position in phenyl propane side chain, and subsequent carboxyl group formation.

Phenolic units show an unusual distribution, with a strong predominance of vanillyl units, amounting to $95 \%$ of the total lignin phenols, in the case of humovitrain (Table 2). In addition, the contents of vanillyl units for lithotypes are well correlated with the total amounts of lignin phenols, which is an indication for the same source contribution ( Fig. 2). A small diversity in phenol group distributions is recognised in the xylain lithotype, where cinnamic units represented $5.3 \%$ of the total phenols.

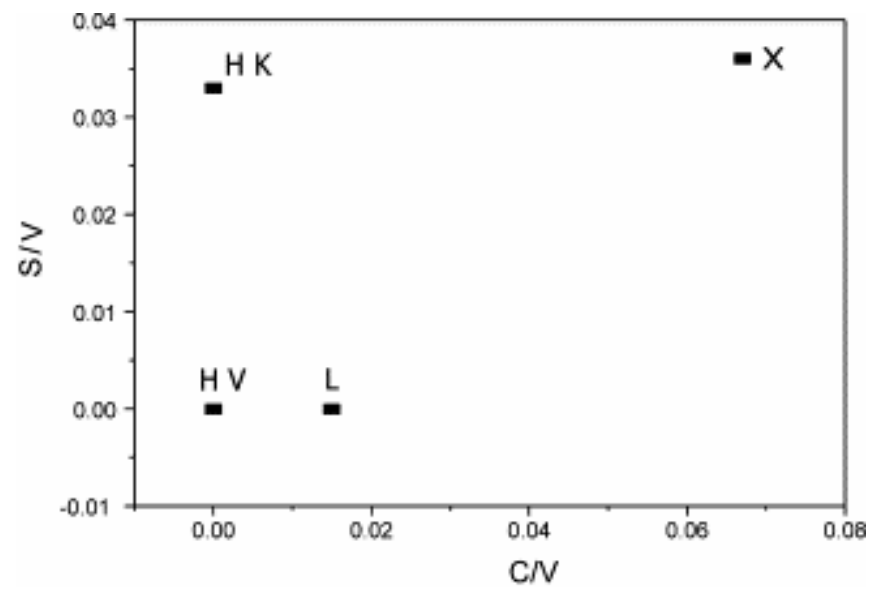

Fig. 2. Plot of lignin-derived phenols ratios in two dimensional diagram, according to Hedges and Mann []] (X, xylain; HV, humovitrain; L, liptain; HK, humoclarain). 
The distribution of phenolic units is interpreted to indicate that gymnosperm woods were predominant precursors for 'Maritza-Iztok' lignite. In the $\mathrm{S} / \mathrm{V}$ vs. $\mathrm{C} / \mathrm{V}$ diagram all samples under study are located near zero in Hedges and Ertel diagram [ㅁ] . This is interpreted as resulting from an approximately equal mixture of woody gymnosperm plant tissues and of non-woody material from other sources. A strong dominance of conifers in the paleoplant community preserved in the 'Maritza-Iztok' lignite is also supported by the biomarker compositions where high contents of $16 \alpha(\mathrm{H})$-Phyllocladane in extracts from the same lithotypes were determined [13].

Low values for $\mathrm{S} / \mathrm{V}$ and $\mathrm{C} / \mathrm{V}$ ratios were plotted in diagram to examine this region in detail (Fig. 3). Higher ratio calculated for xylain in comparison to the other lithotypes could be explained by the presence of non-woody angiosperm tissues, probably originating from marsh or grassland sources. The ratio $\mathrm{C} / \mathrm{V}$ is a useful parameter for discrimination between woody and non-woody vascular plant tissues, since ferulic and $p$-coumaric acids only occur in the latter type of plant material. Another peculiarity is that appreciable quantities of non-woody Gymnospermae should have been present in liptain forming paleoplant community as far as higher than zero value was determined for $\mathrm{C} / \mathrm{V}$ ratio.

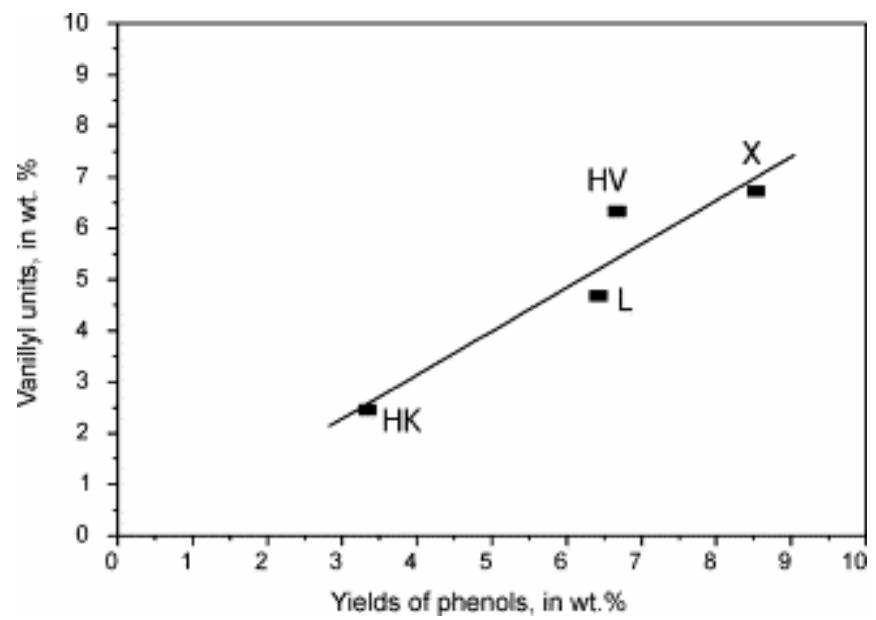

Fig. 3. Relationship between vanillyl units and total phenols produced in $\mathrm{CuO}$ oxidation of lignite lithotypes; (X, xylain; $\mathrm{HV}$, humovitrain; L, liptain; HK, humoclarain).

The content of $2.3 \%$ of syringyl units in products of humoclarain degradation indicates the presence of deciduous trees in paleoenvironment. Since palynologic examination of lignite 'Maritza-Iztok', performed by Sisiskov and Andreev [14], indicated that both Angiospermae and Gymnospermae were sources for the lignite, our study suggests that during coalification compounds syringyl units underwent preferable degradation. Angiospermae due to their greater susceptibility to microbial degradation, are preferably attacked during decay [ㅁ] . In coal structural study other authors came across the same observation. Erol and Olkay [15] have demonstrated that there are reduced quantities of syringyl building blocks in products of $\mathrm{CuO}$ degradation of Turkish lignites with similar palynologic characteristics as lignite 'Maritza-Iztok'.

Hayatsu et al. [ $\underline{7}$ and 16 ] have subjected lignite and higher rank coals to $\mathrm{CuO}$ oxidation at 200 ${ }^{\circ} \mathrm{C}$ for $8 \mathrm{~h}$. The products of degradation lignin-derived monomers were determined. A diversity of hydroxy benzenepolycarboxylic acids and benzene carboxylic acids in prevalence with vanillic acid were the concomitant species. They failed to isolate phenyl propane units. 
With the aim to provide new insight into the use of CZE data one more technique is involved in the study. Since CZE registers only charged compounds it must be admitted that some uncharged molecules were not determined. In Fig. 4 is shown GC separation of xylain $\mathrm{CuO}$ oxidation product and in Table 3 are gathered GC-MS identifications of peaks.

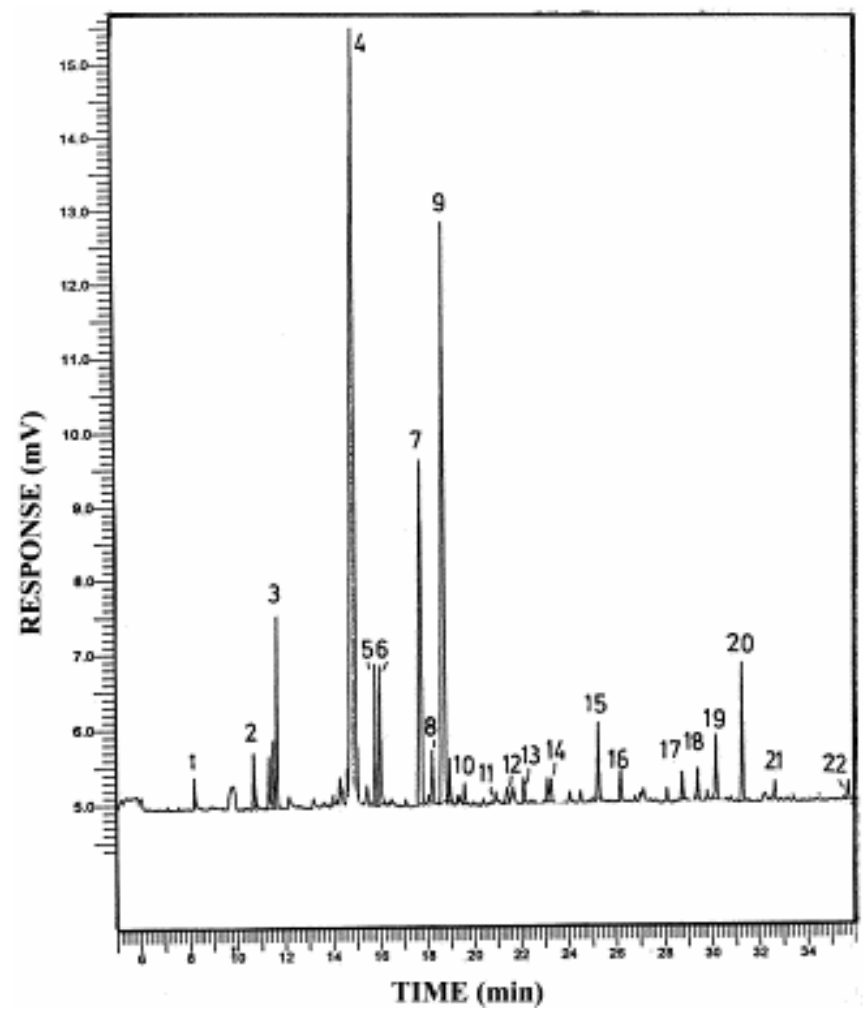

Fig. 4. GC separation of $\mathrm{CuO}$ oxidation products of xylain lithotype; (Peaks identification in $\underline{\text { Table } 3}$ ).

\begin{tabular}{|c|c|c|c|c|}
\hline Peak no. & $\mathrm{RT}(\min )$ & $(\%)$ & Structure & Molecular mass \\
\hline 1 & 8.22 & 0.43 & 4-Hydroxybenzoic acid, methyl ester & 152 \\
\hline 2 & 10.72 & 1.00 & 3-Methoxy-4-hydroxybenzaldehyde (vanillin) & 152 \\
\hline 3 & 11.52 & 1.04 & 4-Methoxybenzoic acid, methyl ester & 166 \\
\hline 4 & 14.90 & 39.17 & 3,4-Dimethoxybenzaldehyde (4-methoxy vanillin) & 166 \\
\hline 5 & 15.80 & 2.39 & $\begin{array}{l}\text { 3-Methoxy-4-hydroxybenzoic acid, methyl ester (Vanillic acid, methyl } \\
\text { ester) }\end{array}$ & 182 \\
\hline 6 & 16.01 & 3.13 & Artefact (ionol) & 220 \\
\hline 7 & 17.77 & 12.70 & 3,4-Dimethoxyacetophenone (4-methoxy acetovanillone) & 180 \\
\hline 8 & 18.24 & 1.27 & 1-(3,4-Dimethoxyphenyl)-propanone & 194 \\
\hline 9 & 18.80 & 21.55 & 3,4-Dimethoxybenzoic acid, methyl ester (Veratric acid, methyl ester) & 196 \\
\hline 10 & 19.61 & 0.40 & hydroxybenzenedicarboxylic acid, dimethyl esters & 210 \\
\hline 11 & 21.47 & 0.50 & 3-(3-Methoxy-4-hydroxyphenyl)-propenoic acid (Ferulic acid) & 194 \\
\hline 12 & 22.16 & 0.55 & $\begin{array}{l}\text { 3-(3-Methoxy-4-hydroxyphenyl)-propenoic acid, methyl ester (Ferulic } \\
\text { acid, methyl ester) }\end{array}$ & 208 \\
\hline 13 & 23.16 & 0.49 & Hydroxybenzenedicarboxylic acid, dimethyl esters & 210 \\
\hline 14 & 23.30 & 0.56 & $\begin{array}{l}\text { 3,4,5- Trimethoxybenzoic acid, methyl ester (4-methoxy syringic acid, } \\
\text { methyl ester) }\end{array}$ & 226 \\
\hline 15 & 25.27 & 1.67 & Internal standard (2,4,5-trimethoxybenzoic acid, methyl ester) & 226 \\
\hline 16 & 26.21 & 0.67 & Methoxybenzendicarboxylic acid, dimethyl esters & 224 \\
\hline 17 & 28.78 & 0.61 & $\begin{array}{l}\text { 3-(3,5-Dimethoxy-4-hydroxyphenyl)-propenoic acid, methyl ester (Sinapic } \\
\text { acid, methyl ester) }\end{array}$ & 238 \\
\hline 18 & 29.43 & 0.64 & Benzoic acid, $o$-( $o$-Toluic), methyl ester & 254 \\
\hline 19 & 30.21 & 1.44 & $\begin{array}{l}\text { 3-(3,4 5-Trimethoxyphenyl)-propenoic acid, methyl ester (4- } \\
\text { methoxysinapic acid, methyl ester) }\end{array}$ & 252 \\
\hline 20 & 31.31 & 2.94 & Pollution (phthalate) & \\
\hline 21 & 32.69 & 0.39 & $n-\mathrm{C}_{16}$ fatty acid, methyl ester & 284 \\
\hline 22 & 35.76 & 0.40 & $n-\mathrm{C}_{18}$ fatty acid, methyl ester & 312 \\
\hline
\end{tabular}

Table 3. GC-MS identification of products of $\mathrm{CuO}$ oxidation of xylain lithotype 
The GC-MS data strongly supported CZE data in several ways:

(i)The main products of alkaline $\mathrm{CuO}$ oxidation were phenolic compounds structurally related to lignin with a prevalence of vanillyl structures.

(ii)Hydroxy benzenedicarboxylic acids are present in negligible quantities. Polycarboxylic benzoic acids and naphthalene structures were not recognised.

(iii)n-Fatty acids in the range $n-\mathrm{C}_{12}$ to $n-\mathrm{C}_{18}$, especially $n-\mathrm{C}_{16}$ and $n-\mathrm{C}_{18}$, were identified in humoclarain sample.

(iv)Phenylpropane units were present at trace levels, but supply useful information for nonwoody contribution.

Certain small peaks represented artefacts, alkylbenzenes (SIM $\mathrm{m} / \mathrm{z}$ 91) and alkane homologues (SIM m/z 57) maximising at $n-\mathrm{C}_{29}$. These compounds could be referred to bitumens inasmuch lithotypes were not preliminary extracted and could not be considered as lignin related species.

\section{Conclusions}

The alkaline $\mathrm{CuO}$ oxidation treatment of lignite at $170{ }^{\circ} \mathrm{C}$ for $4 \mathrm{~h}$, coupled with $\mathrm{CZE}$ identification, is a precise procedure and could be recommended as a mild, reproducible and sensitive technique for evaluation of preserved lignin structures in immature coals. The following values for the contents of preserved lignin related structures in lignite 'MaritzaEast' were determined, in wt\%: xylain, 8.5; humovitrain, 6.7; liptain, 6.4; and, humoclarain, 3.3 .

The oxidative degradation of lithotypes results in lignin monomers with strong dominance of vanillyl phenols. The negligible contents of benzenepolycarboxylic acids, their hydroxy/methoxy counterparts, and the presence of preserved phenylpropane units indicate that the treatment predominantly splits $\beta-\mathrm{O}-4$ bonds in lignins. The presence of coumaric and ferulic acids, evidenced by the two techniques, indicates non-woody tissue contribution to coal formation.

The data suggest a paleoplant community with Gymnospermae domination and minor nonwoody plant contribution. With the advance of coalification process syringyl units were gradually removed and in humovitrain lithotype highly pure vanillic acid building units compose the coal organic matter.

\section{References}

1. J.W. de Leeuw and C. Largeau. In: M.H. Engels and S.A. Macko, Editors, Organic geochemistry, Plenum Press, New York (1993), p. 23.

2. P.G. Hatcher and H.E. Lerch. In: H.H. Schobert, K.D. Bartle and L.J. Lynch, Editors, ACS symposium series 461ACS symposium series 461 vol. II, American Chemical Society, Washington, DC (1991), p. 9.

3. P.G. Hatcher and J.-L. Faulon. Prepr Am Chem Soc Div Fuel Chem 39 (1994), p. 7. 
4. P.G. Hatcher, M.A. Nanny, R.D. Minard, S.D. Dible and D.M. Carson. Org Geochem 23 (1995), p. 881

5. P.G. Hatcher and D.J. Clifford. Org Geochem 27 (1997), p. 251.

6. S.A. Stout, J.J. Boon and W. Spackman. Geochim Cosmochim Acta 52 (1988), p. 405.

7. R. Hayatsu, R.E. Winans, R.L. McBeth, R.G. Scoth, L.P. Moore and M.H. Studier. In: M.L. Gorbaty and K. Ouchi, Editors, Advanced chemistry series 192Advanced chemistry series 192, American Chemical Society, Washington, DC (1981), p. 133.

8. J.I. Hedges and D.C. Mann. Geochim Cosmochim Acta 43 (1979), p. 1803.

9. P.A. Meyers. Org Geochem 27 (1997), p. 213.

10. Maman O. PhD Theses. University of Orleans, France; 1997.

11. J.I. Hedges and J.R. Ertel. Anal Chem 54 (1982), p. 174.

12. O. Maman, F. Marseille, B. Guillet, J.R. Disnar and P. Morin. J Chromatogr A 755 (1996), p. 89.

13. M. Stefanova and C. Magnier. Geol Soc Spec Publ N125 (1997), p. 219.

14. G.D. Sigkov and A.P. Andreev. Compt Rend Acad Bulg Sci 40 (1987), p. 77.

15. M. Erol and A. Olkay. Fuel Sci Techol Int 12 (1994), p. 433.

16. R. Hayatsu, R.E. Botto, R.G. Scott, R.L. McBeth and R.E. Winans. Fuel 65 (1986), p. 821. 